\title{
Polícia e Juízes de Paz na imprensa oitocentista (1826-1829)
}

\author{
DOI: 10.15175/1984-2503-20179303
}

\author{
Joice de Souza Soares ${ }^{1}$
}

\begin{abstract}
Resumo
Criada no início do oitocentos com a chegada da Corte portuguesa ao Brasil, a Intendência Geral da Polícia continuaria funcionando mesmo após a independência e a outorga da Constituição. Por sua vez, o cargo de juiz de paz, previsto na carta magna de 1824, teria sua atividade regulamentada apenas alguns anos mais tarde com a promulgação da lei de 15 de outubro de 1827. Do caráter meramente conciliatório previsto inicialmente, os juízes eletivos congregaram, ainda no fim da década de 1820 , variadas atribuições. A imprensa periódica do século XIX, sobretudo nos primeiros anos após a independência, foi lugar de disputas políticas acerca dos projetos institucionais relacionados à formação do Estado. Nesse sentido, discursos em torno das instituições judiciárias e policiais eram frequentes nos periódicos durante os finais da década de 1820. Figuravam nas páginas dos jornais nesse período correspondências, relatos e textos de opinião a respeito da polícia e dos juízes de paz. Este artigo pretende analisar as perspectivas presentes na imprensa oitocentista sobre a polícia de então e sua relação com o sistema constitucional. Importa, ainda, examinar as expectativas em torno do estabelecimento da magistratura eletiva no que se vinculava às atividades policiais e às novas possibilidades de organização do Estado em construção. O objetivo principal é estabelecer que havia divergências e consonâncias em debate a respeito das instituições judiciárias e policias em transformação, sobretudo no tocante à dificuldade de conciliar a adequação ao sistema constitucional e as heranças do Antigo Regime.
\end{abstract}

Palavras-chave: polícia; juiz de paz; imprensa; política; século XIX.

\section{Policía y jueces de paz en la prensa del siglo XIX (1826-1829)}

\section{Resumen}

Este articulo analiza la posición que la prensa ochocentista tomaba con respecto a la policía y su relación con el sistema constitucional. Examina las expectativas en torno al establecimiento de la magistratura electiva relacionadas con las actividades policiales y las nuevas posibilidades de organización del Estado en construcción. El objetivo principal es cuestionar si existían divergencias y consonancias en debate sobre las instituciones judiciales y policiales en transformación, principalmente en cuanto a la dificultad de conciliar la adecuación al sistema constitucional y las herencias del Antiguo Régimen. Creada a principios del siglo XIX con la llegada de la corte portuguesa a Brasil, la Intendência Geral da Polícia siguió en activo incluso después de la independencia y la firma de la Constitución. Por su parte, la actividad del cargo de juez de paz, contemplado en la carta magna de 1824, se reguló tan solo algunos años después con la promulgación de la Ley brasileña de 15 de octubre de 1827. Del carácter meramente conciliador previsto inicialmente, los jueces electivos poseían, todavía a finales de la década de 1820, variadas atribuciones. La prensa periodística del siglo XIX, sobre todo en los primeros años tras la declaración de la independencia, fue escenario de disputas políticas acerca de los proyectos institucionales relacionados con la formación del Estado. En este sentido, los discursos en torno a las instituciones judiciales y policiales eran frecuentes en los periódicos a finales de la década de 1820. En las páginas de los diarios de la época figuraban correspondencias, relatos y artículos de opinión sobre la policía y los jueces de paz.

Palabras clave: Policía; juez de paz; prensa; política; siglo XIX.

\footnotetext{
${ }_{1}^{1}$ Analista da Fundação Instituto Brasileiro de Geografia e Estatística. Doutoranda no Programa de PósGraduação em História da Universidade Federal do Estado do Rio de Janeiro (UNIRIO). Mestre em História pela Universidade Federal do Estado do Rio de Janeiro. E-mail: joiceesoares@hotmail.com.
} 
The house of silence. Chinese and Mexicans involved in the illegal opium market and related activities in Guadalajara, Jalisco, from 1917 to 1950

\section{Abstract}

Chinese residents of the city of Guadalajara, Jalisco, and from other states such as Sinaloa, played a significant role in the consumption, production, distribution, and illegal sale of opium in the period of 1917 to 1950; however, not all activities may be connected with such residents, as Mexicans more closely linked with marijuana were also steadily incorporated not only in the consumption of opium and its derivatives, but also as producers and traffickers. For its part, the anti-Chinese movements launched in Mexico leading to the massacre of Chinese people in the cities of Torreón (1911) and Chihuahua (1916) and spurring fervent racism in much of the country, forced many Chinese to continue their migration to countries such as the United States, with others deciding to stay in Mexico and become invisible at least in public activities, withdrawing from population censuses and even from activities linked to drug trafficking. It was in the 1940s that information provided by the Guadalajara press itself revealed the predominance of Mexican citizens in the market for opium and its derivatives, with the advent of World War II leading to a surge in prices, before a stabilizing with its end.

Keywords: Racism; drug trafficking; opium; social control; social invisibility.

\section{Police et Juges de paix dans la presse du XIXe siècle (1826-1829) \\ Résumé}

Cet article analyse les perspectives présentées par la presse du $\mathrm{XIX}^{\mathrm{e}}$ siècle en ce qui a trait à la police et à ses relations avec le système constitutionnel. Nous examinerons les expectatives qui ont accompagné l'établissement de la magistrature élective quant aux activités policières et aux nouvelles possibilités d'organisation de l'État en construction. L'objectif principal est de mettre en perspective l'existence, ou non, de divergences et de convergences dans le débat autour des institutions judiciaires et policières en transformation, principalement en ce qui concerne la difficulté à concilier l'adéquation au système constitutionnel et les héritages de l'Ancien Régime. Créée au début du XIXe siècle avec l'arrivée de la Cour portugaise au Brésil, l'Intendance générale de police continuera à fonctionner même après l'indépendance et la proclamation de constitution. De son côté, la fonction de juge de paix, que prévoyait la constitution de 1824 , ne verra ses activités règlementées que quelques années plus tard, lors de la promulgation de la loi du 15 octobre 1827. Au caractère simplement conciliatoire initialement prévu, les juges électifs se verront ajouter de nombreuses attributions dès la fin des années 1820 . La presse du XIXe siècle, principalement lors des premières années suivant l'indépendance, fut la scène de conflits politiques autour des projets institutionnels liés à la formation de l'État. En ce sens, les discours liés aux institutions judiciaires et policières étaient fréquents dans les périodiques de la fin des années 1820. On trouvait dans les pages des journaux de cette époque correspondances, articles et autres éditoriaux opinant sur la police et les juges de paix.

Mots-clés : Police ; juge de paix ; presse ; politique ; XIXe siècle.

\section{9 世纪媒体报道的有关警察和司法调解制度的关系（1826-1829）}

\section{摘要}

本文分析了十九世纪报刊发表的关于警察及其与宪法制度的关系的观点。作者审视了司法调解制度的建立及其 与警察活动的关系，分析了正在建设当中的国家组织的新的可能性。本论文主要目的是质疑司法机构和警察制 度转型中出现的分歧和协调，特别是在调和苵政新制度和君主旧制度的遗存之间遇到的困难。十八世纪初，随 着葡萄牙王室进驻巴西, 在巴西成立了警察总局, 在 1822 年独立和颁布宪法后, 警察总局继续发挥作用。虽 然 1824 年颁布的宪章中规定成立司法调解制度, 但是其活动一直无法可依, 直到 1827 年 10 月 15 日颁布的 法律对司法调解与仲裁制度进行了规定。最初调解官的职责是单纯的司法调解与仲裁, 随着时间推移, 到 20 世纪 20 年代末, 调解官的责任范围不断扩大, 包含了很多基层法官的民事登记, 调解与仲裁的功能。十九世 纪的报纸杂志, 特别是巴西独立后的头几年, 大量报道了与国家形成有关的机构的设定及其政治争端。直到 20 世纪 20 年代末, 有关司法和警察机构的关系的话语仍旧频频发生, 有关警方和司法调解官之间的䏌系的报 道，报告和意见，在报纸和杂志的页面仍然随处可见。

关键词 : 警察 ; 民事调解官; 媒体; 政治 ; 十九世纪 
Após a emancipação do Brasil, em 1822, e, mais especificamente, após a outorga da Constituição em 1824, uma série de transformações institucionais seriam realizadas. Tratava-se da tentativa de adequar o novo Estado aos primados da lei e da constitucionalidade.

O período iniciado em 1826, com a primeira legislatura da Assembleia Geral, foi marcado por intensos debates acerca de temas importantes para o momento político. No parlamento, discutiam-se a constitucionalidade das leis, as mudanças institucionais, a ação dos ministros de Estado, as atividades e a responsabilização dos empregados públicos. Entre as transformações empreendidas nesse ínterim, pode-se mencionar a promulgação da lei de 15 de outubro de $1827,{ }^{2}$ que regulamentava a atividade dos juízes de paz, e a criação da lei que transformou a organização das Câmaras Municipais, de 1ำ de outubro de $1828 .^{3}$

A magistratura eletiva não era novidade no Brasil que, durante os anos coloniais, contou com a figura dos juízes ordinários, funcionários eleitos dos conselhos municipais, unidade básica da estrutura administrativa e judicial portuguesa. ${ }^{4}$ Contudo, com a Constituição de 1824, a figura dos juízes eleitos ganhava nova forma.

O artigo n. 161 da Constituição do Império estabelecia que nenhum processo seria iniciado sem a tentativa de reconciliação entre as partes. E, para tanto, o artigo seguinte demarcava a instituição dos juízes de paz, eleitos pelo mesmo modo e pelo mesmo tempo que os vereadores das Câmaras Municipais. ${ }^{5}$ De fato, entre a disposição trazida pela carta constitucional e as atribuições conferidas aos magistrados eletivos já no fim da década de 1820, havia uma distância significativa.

\footnotetext{
2 BRASIL. Congresso Nacional. Câmara dos Deputados. Lei de 15 de outubro de 1827. 1827. Crêa em cada uma das freguezias e das capellas curadas um Juiz de Paz e supplente.. Disponível em: <http://www2.camara.leg.br/legin/fed/lei_sn/1824-1899/lei-38396-15-outubro-1827-566688publicacaooriginal-90219-pl.html>. Acesso em: 18 dez. 2015.

${ }^{3}$ BRASIL. Presidência da República. Casa Civil. Subchefia para Assuntos Jurídicos. Lei de 1ํ de outubro de 1828. 1828. Dá nova fórma ás Camaras Municipaes, marca suas attribuições, e o processo para a sua eleição, e dos Juizes de Paz. Disponível em: <http://www.planalto.gov.br/ccivil_03/leis/LIM/LIM-1-101828.htm>. Acesso em: 6 abr. 2016.

${ }^{4}$ CAMPOS, Adriana P. O farol da boa prática judiciária: dois manuais para instrução dos juízes de paz. In: SIMPÓSIO NACIONAL DE HISTÓRIA. LUGARES DOS HISTORIADORES: VELHOS E NOVOS DESAFIOS, 28, 2015, Florianópolis. Anais eletrônicos.... Florianópolis: ANPUH, 2015. Disponível em: <http://www.snh2015.anpuh.org/resources/anais/39/1428359222_ARQUIVO_Floripa-Anpuh.pdf>. Acesso em: 8 abr. 2016.

${ }^{5}$ BRASIL. Presidência da República. Casa Civil. Subchefia para Assuntos Jurídicos. Constituição política do Império do Brasil (de 25 de março de 1824). 1824. Disponível em: <http://www.planalto.gov.br/ccivil_03/Constituicao/Constituicao24.htm>. Acesso em: 6 abr. 2016.
} 
Se, a princípio, o papel conferido aos juízes de paz estaria vinculado a atividades de conciliação na fase preliminar dos processos, nos anos seguintes, sobretudo a partir dos anos de 1830, seriam deslocadas para sua alçada as principais atividades relacionadas ao exercício do poder policial e da administração inicial da justiça criminal.

As críticas ao judiciário colonial, que serviam como justificativa para o aumento das atribuições conferidas aos juízes de paz, se vinculavam aos abusos de poder dos magistrados togados e, ainda, à ineficiência judicial. Havia também a perspectiva de que com a descentralização judiciária, ao nível das localidades com os magistrados eleitos, a administração da justiça poderia ser levada a todas as partes do Império. ${ }^{6}$

A lei de 15 de outubro de 1827 e, principalmente, a de $1^{\circ}$ de outubro de 1828 conferiam aos juízes de paz uma série de atribuições. No caso do último dispositivo legal, seriam deslocados para os juízes eletivos diversas funções antes conferidas à Câmara Municipal. ${ }^{7}$ Cabe destacar que a lei de 1828 determinava funções meramente administrativas para as Câmaras, esvaziando-as assim de seu poder político, marca da atuação dessas instituições durante os anos coloniais. Ainda assim, é possível estabelecer que a promulgação do Código de Processos em 1832 realizaria a consolidação de um processo de afirmação da magistratura eletiva no ordenamento jurídico e na estrutura policial do Império.

Considerando a importância adquirida pelas localidades no fim da década de 1820 e, mormente, nos anos de 1830, torna-se de suma importância a análise dos discursos políticos sobre os juízes de paz e a polícia no primeiro período de mudanças institucionais após a independência. Tais aspectos não passariam despercebidos pela imprensa periódica que despontava como elemento fundamental nos enfrentamentos e debates políticos daquele momento. O processo que se iniciara com as contendas sobre a independência ganhava força nos anos seguintes, consolidando os periódicos como um canal essencial para o estabelecimento e a divulgação das ideias - e disputas - políticas.

Assim, a imprensa periódica do período é compreendida neste artigo como muito mais que um veículo capaz de ilustrar os debates políticos que aconteciam na Assembleia

\footnotetext{
6 VELLASCO, Ivan. O juiz de paz e o Código do Processo: vicissitudes da justiça imperial em uma comarca de Minas Gerais no século XIX. Justiça \& História, Porto Alegre, v. 3, n. 6, p. 65-93, 2003. Disponível em: <https://bdjur.stj.jus.br/jspui/bitstream/2011/66121/juiz_paz_codigo_vellasco.pdf>. Acesso em: 18 abr. 2016. $7 \mathrm{O}$ artigo $\mathrm{n}$. ${ }^{\circ} 80$ da lei de $1^{\circ}$ de outubro de 1828 estabelecia que a Câmara Municipal deveria nomear um procurador que, dentre suas atividades, deveria "demandar perante os juízes de paz a execução das posturas e a imposição das penas aos contraventores delas". Por sua vez, o artigo n. ' 88 estabelecia que os juízes de paz seriam "privativos para julgarem as multas por contravenções às posturas das Câmaras a requerimento dos procuradores delas ou das partes interessadas". BRASIL, 1828, art. 80.
} 
Legislativa acerca das transformações institucionais do Estado em construção. Os jornais despontavam como instrumento de disputa política na redefinição do espaço público e das sociabilidades no oitocentos. Nesse sentido, a imprensa de opinião que se consolidava ao longo dos anos de 1820 torna-se um dos elementos fundamentais para a compreensão da própria dinâmica política do período. ${ }^{8}$

Despontavam nesse cenário homens de letras que teciam suas considerações sobre as mudanças institucionais, a composição dos ministérios e o sistema político nas páginas dos jornais. Na redefinição dos espaços de participação política, a imprensa se destacava como componente primordial.

Com a instalação da Assembleia Geral, teriam sido criadas as condições necessárias para o desenvolvimento da imprensa periódica de opinião. ${ }^{9}$ Em jornais de tendência liberal, nos anos finais da década de 1820, eram publicados comentários a respeito das discussões parlamentares e textos tratando de conceitos vinculados à constitucionalidade e à liberdade; eram também veiculadas correspondências de leitores nas quais temas caros ao momento eram abordados, bem como eventos cotidianos narrados, tecendo relações com os acontecimentos políticos do período.

Os redatores manifestavam-se sobre a defesa da Constituição, do sistema representativo, das instituições eletivas e das municipalidades. Da mesma forma, eram feitas críticas às instituições oriundas do Antigo Regime, aos empregados públicos e aos ministros de Estado; estaria sempre presente a condenação do despotismo e do absolutismo. ${ }^{10}$

Os embates diretos e a desqualificação dos opositores, sendo pessoas ou periódicos, seriam uma constante $; 11$ a retórica se torna, assim, um elemento fundamental para o entendimento das disputas discursivas no período. ${ }^{12}$ A opinião pública, cara aos liberais constitucionais daquele momento, ganharia a feição de um tribunal. ${ }^{13}$

Por essa razão, neste artigo serão analisados alguns dos posicionamentos presentes nos jornais A Malagueta, Astréa e Aurora Fluminense, de tendência liberal,

\footnotetext{
${ }^{8}$ MOREL, Marco. As transformações dos espaços públicos: imprensa, atores políticos e sociabilidades na cidade imperial (1820-1840). São Paulo: Hucitec, 2005.

9 SODRÉ, Nelson Werneck. História da imprensa no Brasil. 4. ed. Rio de Janeiro: Mauad, 1999, p. 98.

10 Discussão importante sobre a presença dos epítetos absolutismo e despotismo na imprensa, sobretudo no período das discussões sobre a independência, pode ser encontrada em: NEVES, Lúcia M. B. P. Corcundas e constitucionais: a cultura política da independência (1820-1822). Rio de Janeiro: Revan, 2003.

11 SODRÉ, Nelson Werneck. História da imprensa no Brasil. 4. ed. Rio de Janeiro: Mauad, 1999.

${ }^{12}$ CARVALHO, José Murilo. História intelectual no Brasil: a retórica como chave de leitura. Topoi, Rio de Janeiro, n. 1, p. 123-152, jan./dez. 2000.

${ }^{13}$ MOREL, Marco; BARROS, Mariana M. Palavra, imagem e poder: o surgimento da imprensa no Brasil do século XIX. Rio de Janeiro: DP\&A, 2003.
} 
publicados na Corte do Império, relacionados às transformações nas instituições policiais e ao estabelecimento dos juizados de paz.

A primeira aparição de $A$ Malagueta foi no início da década de 1820. Redigido por Luís Augusto May, o periódico fora publicado em quatro fases distintas: a primeira, de 18 de dezembro de 1821 a 5 de junho de 1822; a segunda, de 31 de julho de 1822 a 10 de julho de 1824 - as chamadas Malaguetas Extraordinárias; a terceira, de 19 de setembro de 1828 a 28 de agosto de 1829 - que é objeto de análise neste artigo; e a quarta, de 2 de janeiro 1831 a 31 de março de 1832.

O jornal alcançou grande repercussão e Luís Augusto May, que fora militar e funcionário do governo português, tornou-se deputado na primeira legislatura, em 1826, sendo reeleito para a segunda, em 1831. Geralmente, as edições do periódico eram compostas por um artigo de opinião de seu redator, publicadas ora uma, ora duas vezes por semana. Os posicionamentos eram de dura oposição ao governo e ao imperador. ${ }^{14}$ As opiniões políticas de May acabaram rendendo-Ihe dois atentados, um em 1823 e outro em 1829, o que demonstra o quanto a imprensa periódica era parte fundamental das disputas políticas do período.

O periódico Astréa, publicado pela primeira vez em 6 de maio de 1826, logo após a instalação da Assembleia Geral, fora redigido por Antônio José do Amaral e José Joaquim Vieira Souto, circulando até 1832. O jornal ganharia importância nos anos finais da década de 1820 e na conturbada fase que precedeu a abdicação de D. Pedro I. ${ }^{15}$ As publicações ocorriam três vezes por semana, às terças, quintas e sábados, e, geralmente, contavam com um artigo de opinião dos redatores e seções destinadas a correspondências dos leitores, além de, quase sempre, uma parte destinada ao acompanhamento dos debates ocorridos na Assembleia Geral.

De perfil semelhante era $A$ Aurora Fluminense, periódico que começara a ser publicado em 21 de dezembro de 1827 e circularia até 1835. Inicialmente, seus redatores eram José Apolinário de Morais, Francisco Valdetaro e José Francisco Sigaud. Pouco tempo depois, Evaristo da Veiga juntou-se ao grupo, tornando-se seu único redator logo em seguida. O jornal adotaria uma "posição equidistante dos extremos", ${ }^{16}$ provocando a

\footnotetext{
${ }^{14}$ SODRÉ, 1999, p. 61.

15 Ibidem, p. 98.

16 Ibidem, p. 107.
} 
ira dos periódicos alinhados ao governo e "reparos nas folhas mais violentas de oposição". ${ }^{17}$

A Aurora era publicada três vezes por semana, às segundas, quartas e sextas. As edições eram compostas por uma seção destinada ao interior do país, uma ao Rio de Janeiro, outra ao exterior e uma a "variedades". Em geral, nesta última eram publicadas correspondências de leitores, traduções e citações. Nas seções destinadas ao interior e ao Rio de Janeiro, havia comentários acerca das publicações realizadas em outros periódicos, alinhados ou não à tendência política da Aurora, quer fosse para corroborar ou criticar seus posicionamentos. O periódico também se tornaria um dos principais jornais liberais no final da década de 1820 e, nas eleições para a segunda legislatura, Evaristo da Veiga seria eleito deputado.

O combate ao absolutismo e aos áulicos empreendido nas páginas do periódico redigido por Evaristo da Veiga eram frequentes também nas folhas da Astréa. Em geral, a oposição era aos ministros de Estado, mas a figura do imperador era poupada. Com os acontecimentos que desencadearam a abdicação no início da década de 1830, esse posicionamento seria revisto. Entretanto, os excessos eram rechaçados. A defesa era a da Constituição, jamais a da revolução. ${ }^{18}$

Lançar luz sobre as perspectivas, expectativas e projetos políticos presentes em alguns dos periódicos do período pode contribuir para o entendimento do processo de constituição, transformação e legitimação das instituições policiais em sua relação com a construção do Estado. É nesse sentido que, a seguir, serão apresentados e analisados alguns dos posicionamentos acerca do sistema constitucional e sua compatibilidade com as instituições policiais, bem como sobre a instituição da magistratura eletiva.

\section{O sistema constitucional e a polícia em fins da década de 1820}

O estabelecimento da polícia no Brasil remonta ao início do século XIX, a partir da chegada da Corte portuguesa. Em 1808, fora criada a Intendência Geral da Polícia da Corte e do Estado do Brasil por meio do alvará de 10 de maio:19 o cargo de intendente da polícia teria a mesma forma e jurisdição que tinha o de Portugal. No ano seguinte, por

\footnotetext{
17 SODRÉ, 1999, p. 107.

18 lbidem, p. 107-108.

19 BRASIL. Congresso Nacional. Câmara dos Deputados. Alvará de 10 de maio de 1808. 1808. Crêa o logar de Intendente Geral da Policia da Corte e do Estado do Brazil. Disponível em: <http://www2.camara.leg.br/legin/fed/alvara/anterioresa1824/alvara-40149-10-maio-1808-572058publicacaooriginal-95179-pe.html>. Acesso em: 20 nov. 2015.
} 
meio do decreto de 13 de maio, seria instituída a Divisão Militar da Guarda Real da Polícia, cujo comandante estaria subordinado ao intendente e ao governador de armas da Corte, ${ }^{20}$ um corpo militarizado responsável pelo patrulhamento da cidade.

As áreas de atuação da Intendência eram várias. Vinculavam-se a ações de segurança pública, saúde, conflitos conjugais e familiares e ao recrutamento para postos militares. ${ }^{21}$ Também estavam sob sua responsabilidade aspectos relacionados à organização do espaço urbano, como a construção de estradas e pontes, à iluminação pública, ao abastecimento de água e, ainda, ao apresamento de escravos fugitivos. ${ }^{22}$

Distintas atividades relacionadas, sobretudo, à concepção de polícia que predominava no Antigo Regime. Nesse sentido, a polícia não seria apenas uma "instituição ou um mecanismo funcionando no seio do Estado, mas uma técnica de governo própria ao Estado; domínios, técnicas, objetivos que apelam a intervenção do Estado". ${ }^{23}$ Assim, a polícia se vinculava mais diretamente à gestão da vida dos súditos e, no meio urbano, estaria relacionada à administração interna da cidade nos pontos que mais interferiam no seu cotidiano. ${ }^{24}$

Após a independência do Brasil, em 1822, e a promulgação da Constituição de 1824, contudo, as instituições policiais criadas no início do oitocentos continuaram em funcionamento. Não obstante, a construção de um Estado independente e constitucional demandava novas instituições; o refazer do sistema jurídico se impunha. Nesse sentido, colocavam-se para os contemporâneos dois desafios: a impossibilidade de se conceber um sistema completamente novo e nacional, desprezando as matrizes coloniais portuguesas; e o impedimento de criar-se um sistema de todo liberal-constitucional, no

20 BRASIL. Congresso Nacional. Câmara dos Deputados. Decreto de 13 de maio de 1809. 1809. Crêa a divisão militar da Guarda Real da Policia no Rio de Janeiro. Disponível em: <http://www2.camara.leg.br/legin/fed/decret_sn/anterioresa1824/decreto-40054-13-maio-1809-571685publicacaooriginal-94831-pe.html>. Acesso em: 20 nov. 2015.

21 SILVA, Maria Beatriz Nizza da. A Intendência-Geral da Polícia: 1808-1821. Acervo: Revista do Arquivo Nacional, Rio de Janeiro, v. 1, n. 2, p. 137-251, jul./dez. 1986.

Um breve panorama sobre a Intendência Geral da Polícia, em Portugal e no Brasil, pode ser encontrado em: COTTA, Francis Albert. Matrizes do sistema policial brasileiro. Belo Horizonte: Crisálida, 2012, p. 43106.

22 HOLLOWAY, Thomas H. Polícia no Rio de Janeiro: repressão e resistência numa cidade do século XIX. Rio de Janeiro: Fundação Getúlio Vargas, 1997.

${ }^{23}$ FOUCAULT, Michel. "Omnes et singulatim": uma crítica da razão política. In: MOTTA, Manoel Barros da (Org.). Ética, estratégia, poder-saber. 3. ed. Rio de Janeiro: Forense Universitária, 2012, v. 4, p. 369. Coleção Ditos \& Escritos.

24 SEELAENDER, Airton C. L. A "polícia" e as funções do Estado: notas sobre a "polícia" do Antigo Regime. Revista da Faculdade de Direito, Curitiba, n. 49, 2009, p. 77. 
conteúdo e na forma, considerando a ordem tradicional pautada em privilégios e patrimonialismos. ${ }^{25}$

Pode-se estabelecer que ao Direito, sobretudo àquilo que se pode chamar de Direito público ${ }^{26}$ - e às instituições relacionadas à administração da justiça -, fora conferido um papel essencial na construção do novo Estado. Entretanto, esse mesmo processo seria marcado por rupturas, continuidades e hibridizações. ${ }^{27}$

Os postulados caros aos liberais da época, sobretudo vinculados à defesa da Constituição, ao primado das leis, ao combate ao arbítrio e à discricionariedade dos magistrados togados e dos agentes policiais, ao elogio do sistema representativo e, principalmente, à Câmara dos Deputados apareceriam de forma frequente na imprensa do período.

De forma análoga, a defesa de um liberalismo constitucional - que compreendia Constituição quase como sinônimo de liberdade ${ }^{28}$-, sem alteração significativa nos sentidos conferidos à representação política, ${ }^{29}$ também se fazia presente. Para a maioria dos liberais da década de 1820, a liberdade constitucional seria o oposto à anarquia; a monarquia seria a garantia de segurança; as críticas seriam dirigidas aos funcionários públicos e aos ministros de Estado, não ao imperador.

É nesse sentido que, em 22 de março de 1827, o jornal Astrea ${ }^{30}$ publicava uma correspondência, ao que parece inicialmente enviada a um periódico de São Paulo - $O$ Farol Paulistano - em que ficava estabelecida a completa incompatibilidade entre o sistema constitucional e a polícia.

Para o correspondente, que assinava como $O$ tranquilo, a polícia geral seria um flagelo das monarquias absolutas que insistia em existir, oriunda de tempos em que a

\footnotetext{
${ }^{25}$ LOPES, José Reinaldo de Lima. Iluminismo e jusnaturalismo no ideário dos juristas da primeira metade do século XIX. In: JANCSÓ, Istvan (Org.). Brasil: formação do Estado e da nação. São Paulo: Hucitec, 2003, p. 195-218.

26 Ibidem.

27 Sobre um breve panorama conceitual a respeito da transição da política do Antigo Regime para a política moderna: GUERRA, François-Xavier. De la política antigua a la política moderna: algunas proposiciones. Anuario IEHS, Buenos Aires, n. 18, p. 201-212, 2003.

28 MATTOS, Ilmar Rohllof. Construtores e herdeiros: a trama dos interesses na construção da unidade política. Almanack Brasiliense, São Paulo, n. 1, p. 8-26, 2005.

${ }^{29}$ Sobre o distanciamento, já no período pós-independência, entre a estrutura político-institucional e as demandas múltiplas da sociedade, dentre elas a ampliação dos canais de representação: SLEMIAN, Andréa. Os canais de representação política nos primórdios do Império: apontamentos para um estudo da relação entre Estado e sociedade no Brasil (1822-1834). Lócus: Revista de História, Juiz de Fora, v. 13, n. 1, p. 34-51, 2007.

30 Todos os periódicos citados neste artigo foram consultados na hemeroteca digital da Biblioteca Nacional: $<$ http://bndigital.bn.br/hemeroteca-digital/>.
} 
razão não se fazia presente, vinculada aos ditames da vingança e da suspeita. ${ }^{31}$ Para 0 leitor e correspondente, a justificativa dada pelos governos de que a polícia serviria para a manutenção da ordem e para auxiliar a justiça não era convincente. A polícia serviria, sob sua perspectiva, para que, "temendo as luzes da civilização", os governos encobrissem "esse infernal sistema de espionagem e vingança". ${ }^{32}$ Entre as acusações que pesavam sobre a instituição policial estavam aquelas vinculadas ao excessivo poder conferido ao intendente e a não observância da lei pelos agentes policiais.

As críticas à polícia não eram novidade. No ano anterior, logo após o início das atividades da Assembleia Legislativa, o mesmo periódico havia publicado uma correspondência de um leitor que se intitulava $O$ estudante. Afirmava o correspondente que, no caos de sua gaveta, havia encontrado a tradução de dois capítulos da obra do Conde Delabord e pedia sua publicação no jornal, posto que se tratava de um tema importante para as discussões das casas legislativas.

Os capítulos publicados pela Astréa também diziam respeito à incompatibilidade entre a polícia tal qual estava estabelecida e a Constituição. Segundo o extrato reproduzido no jornal, "[...] se a carta que funda a liberdade individual é observada, a polícia geral fica sem ação e sem fins a que se dirija”. ${ }^{33}$ Por sua vez,

[...] se os direitos de liberdade constitucional estão em sua plenitude e se, não obstante, a polícia geral põe em ação todos os seus atos arbitrários que o são por natureza, tais como: supressões de obras, visitas domiciliares, detenções, prisões e desterros; a carta é aniquilada. ${ }^{34}$

O antagonismo entre a Intendência da Polícia e a Constituição não seria negado nem por aqueles que defendiam sua manutenção. Em correspondência datada de 17 de agosto de 1826, ${ }^{35}$ Um amigo da verdade e da pátria afirmava a necessidade da existência de uma polícia geral no Brasil até que os brasileiros obtivessem genuinamente uma "educação liberal", ou seja, que "se liguem à Sociedade Brasílica por anéis verdadeiramente constitucionais; e que não queiram formar degraus uns sobre as costas dos outros para subirem a seus fins". ${ }^{36}$

O correspondente que escrevia ao redator da Astréa, a fim de responder à carta do leitor $O$ estudante, afirmava seu desejo de

\footnotetext{
31 Astréa, n. 113, 22 mar. 1827, p. 457.

32 Ibidem, p. 458.

${ }^{33}$ Astréa, n. 22, 12 ago. 1826, p. 87.

34 Ibidem.

35 Não há numeração na correspondência enviada, apenas data.

36 Disponível na hemeroteca da Biblioteca Nacional como "Edição 0001", colocado junto aos números do ano de 1832.
} 
[...] conceder que a polícia geral não sirva, e até que seja incompatível nos governos liberais; porém eu vejo que um dos objetos que por ora mais tem merecido a atenção e emprego de trabalho da mesma é desta espécie humana, a que se chamam $=$ pretos!

Ora sendo bom, e até natural, que a cada passo invoquemos os santos, em qualquer oportunidade e empresa, contudo, eu nesta análise, ou n'alguma consideração de pretos, jamais desejarei lembrar-me de S. Domingos... de S. Domingos!!!37

O medo de uma rebelião de negros nos moldes daquela ocorrida na ilha de São Domingos no Haiti, ainda no fim do século XVIII, aparecia como uma das razões para a manutenção da polícia tal qual se achava instituída, mesmo nos tempos de Constituição.

Em 3 de fevereiro de 1827, o periódico redigido por Antônio José do Amaral e José Joaquim Vieira Souto publicava um artigo elogiando as ações empreendidas pela instituição policial. Nesta edição, havia um quadro com os números dos indivíduos presos pelos comissários de polícia na província do Rio de Janeiro. Conforme estabelecido na publicação, "este mapa manifesta a vigilância da polícia sobre os homens perturbadores do sossego da província". Entre as categorias apresentadas, ${ }^{38}$ o número de escravos fugitivos que teriam sido apreendidos era mais que o dobro da soma de todos os outros presos. $^{39}$

Ainda que não tratando especificamente da questão relacionada à existência da Intendência Geral no seio de um Estado que se pretendia constitucional, o Inimigo de ladrões como do despotismo escrevia ao redator da Astréa problematizando seu entusiasmo para com os números apresentados pela Intendência da Polícia, relacionados às ações de seus comissários. ${ }^{40} \mathrm{O}$ correspondente havia se surpreendido "de ver a pouca caridade com que Vm., sem entrar na indagação de serem ou não justas semelhantes prisões, declama contra os presos e louva a atividade dos comissários". ${ }^{41}$ A preocupação estaria vinculada à possibilidade de abusos e arbitrariedades por parte dos agentes policiais.

\footnotetext{
${ }^{37}$ Disponível na hemeroteca da Biblioteca Nacional como "Edição 0001", colocado junto aos números do ano de 1832 ..

38 Desertores da primeira linha; ditos da marinha; homens livres por deserção; ditos entregues à justiça; ditos ao quartel general; doidos entregues à misericórdia; ditos a diversos juízes; escravos fugidos; ditos furtados; ditos entregues à justiça; homens livres ao quartel general para a praça; ditos para a marinha.

${ }^{39}$ Seriam 1098 escravos fugitivos detidos ao longo do ano de 1826. O número total de presos, somando todos os outros motivos para as prisões, seria de 445.
}

Astréa, n. 93, 3 fev. 1827, p. 376.

40 A questão em torno dos comissários gerou controvérsias na imprensa do período. Criados pela portaria $\mathrm{n}$. 252, de 4 de novembro de 1825, e não por lei, esses agentes policiais enfrentaram resistências nas páginas dos periódicos. A Aurora Fluminense, n. 144, de 21 de janeiro de 1829, p. 595.

${ }^{41}$ Astréa, n. 106, 6 mar. 1827, p. 429. 
A própria noção da polícia enquanto auxiliar da justiça seria questionada. Conforme extrato do Farol Paulistano publicado na Astréa em maio de 1828, justiça e polícia formariam uma "aliança de palavras e ideias que se repulsam e se excluem mutuamente", ${ }^{42}$ pois a polícia seria a própria evidência da tirania.

As explanações sobre a impossibilidade de coexistirem a polícia tal como se achava estabelecida e a Constituição, com seus mecanismos de garantia e defesa das liberdades individuais, não apareciam apenas de forma abstrata. Os relatos de ações policiais pautadas no arbítrio, na discricionariedade e na violência também figuravam nas páginas dos periódicos.

Na edição de 6 de setembro de 1827, um leitor escrevia para a Astréa a fim de denunciar um fato do qual havia tomado conhecimento. Segundo consta no periódico, o correspondente $O$ carioca constitucional narrava que, no dia 12 de agosto daquele ano, "estando uns pretos a brincar, dançando, foram levados à Guarda principal; e aí, sobre o fundo de uma tina emborcada, agarrados, apanharam uma grande doze de varadas e, ainda depois que os largavam, iam levando até a escada".43

A carta enviada pelo correspondente Um dos que não querem as cebolas do Egito à Aurora Fluminense trataria de tema semelhante. Conforme a narrativa presente na edição publicada em 15 de outubro de 1828,

\begin{abstract}
[...] indo no dia 9 do corrente tomar o fresco ao Campo da Aclamação, entretinhame a observar o grande tumulto que havia no exótico chafariz, motivado pela extrema penúria d'água, e a ver com lástima a imensidade de pretos que ali se amontoavam, as pancadas que davam uns nos outros, os barris que quebravam e, enfim, os que voltavam para casa, sem água e sem barril; eis que de repente vejo dois soldados da polícia, armados de paus, fazendo ir à força para o seu quartel os pretos e pretas que há muito custo, e depois de tempo imenso perdido, traziam água para seus srs., e como alguns destes escravos não obedecessem prontamente, os soldados não só os maltratavam com pauladas, mas até lhes lançavam ao chão os barris que tinham à cabeça. ${ }^{44}$
\end{abstract}

Em um artigo de opinião publicado na Astréa em agosto de 1828, tratou-se das ações da polícia no tocante ao direito de inviolabilidade do domicílio. Segundo consta no periódico, "Fuão de tal, acompanhado de dois esbirros auxiliados por soldados da Guarda da Polícia" 45 teria dado buscas em casas da Travessa do Paço. Pelo que se pode compreender da história, o tal Fuão e os soldados tinham um despacho do ajudante do

\footnotetext{
42 Astréa, n. 278, 3 maio 1828, p. 1153.

43 Astréa, n. 183, 6 set. 1827, p. 750.

44 A Aurora Fluminense, n. 104, 15 out. 1828, p. 435.

45 Astréa, n. 317, 12 ago. 1828, p. 1309.
} 
intendente da polícia para apreender todos "os trastes de ouro e prata que encontrassem"46 e, talvez, as pessoas da casa.

Ao chegarem à casa de n. 6 , encontraram um oficial militar da primeira linha do exército. Para além dos pormenores da notícia, cabe mencionar a denúncia trazida pelo jornal: a busca teria violado a Constituição por não haver menção explícita no despacho sobre a casa a ser revistada e sobre as pessoas que nela residiam; e por ter sido feita à noite, não se tratando de caso de incêndio ou inundação. ${ }^{47}$ Assim, asseverava-se que:

O sr. ajudante do intendente geral da polícia deu cumprimento à Constituição e citadas leis com um despacho autorizando um homem para ir com esbirros da polícia, auxiliados pela força armada, a dar busca em todas as casas que (em virtude de denúncias que esse homem declarou estar recebendo em segredo) Ihe devem ser suspeitas; e além disto para conduzir os trastes de prata e ouro que encontrar - com um despacho, nova espécie de cartas brancas com que nos quer brindar este senhor.

Com essas portarias vagas, incuriais, indeterminadas e inconstitucionais, leva o senhor ajudante do intendente geral da polícia o alarma ao centro das famílias e todas ficam expostas, bem que honradas sejam, aos insultos da imoralidade da gente empregada nessas correrias, e aos efeitos da vingança que delas queiram tirar pessoas que lhe sejam desafetas.

Nem um cidadão quer que se lhe lance inopinadamente o alarma e o terror no seio de sua família, não deseja que lhe penetrem arbitrariamente a sua casa, surpreendendo no fundo do seu asilo sua mulher e filhas, o que todos consideram uma investigação sacrílega. A Constituição preservou-as deste flagelo garantindoIhes a inviolabilidade de seu domicílio; porém o senhor ajudante do intendente da polícia manda o contrário porque é sua absoluta vontade que assim seja. 48

Os relatos enviados pelo Sindicante do procedimento do alcaide da polícia também seguiam a linha de denúncia contra arbitrariedades. Conforme o correspondente, Valentim José dos Santos havia sido vítima de roubo em sua própria residência e os bens subtraídos vendidos a outras pessoas. Por essa razão, o juiz do crime da Candelária teria decidido que fossem conduzidos os escravos, autores do roubo, e os suplicados na forma requerida.

A partir de então, o alcaide da polícia teria cumprido a determinação da forma que bem Ihe aprouve. Assim, teria ido muito além de sua autoridade e conduzido busca, sem presença de oficial de justiça, na casa de várias pessoas. Fato que teria, no limite, levado ao questionamento do correspondente:

Sr. redator, o que eu desejava saber é se o alcaide da polícia está autorizado para avançar o seu orgulhoso entusiasmo a adiantar-se das ordens de que vai autorizado pelos seus superiores; porque a chegar a tanto a sua alçada, estamos sujeitos a que, quando o dito alcaide receber ordem para alguma intimação, imediatamente recolhe o sujeito à cadeia e o remédio é obedecer-Ihe sem a mais

\footnotetext{
${ }^{46}$ Astréa, n. 317, 12 ago. 1828, p. 1309.

47 Ibidem.

48 Ibidem, p. 1310.
} 
pequena repugnância se não quiser sofrer algum auto de resistência; a mim me parece bem intolerável este mau comportamento de um alcaide [...]. ${ }^{49}$

Por sua vez, o correspondente que assinava como Um seu constante leitor enviara para a Astréa o relato que saíra publicado na edição de 20 de dezembro de 1828 . Conforme a narrativa, o comissário de polícia José Ribeiro da Cruz Portugal teria agido com "despotismo e ferocidade".

O correspondente teria ido para sua casa em Cascadura, no distrito de Inhaúma, com três de seus escravos. Chegando primeiro ao destino, o correspondente teria escutado gritos clamando por socorro pouco tempo depois. Ao ir em direção ao local onde haviam sido feitos os pedidos de ajuda, percebeu que seus escravos estavam com um capitão do mato que não se convenceu de ser o constante leitor o dono dos cativos.

O correspondente relatou que chamou seus escravos de volta para casa, mas o tal capitão teria iniciado as agressões contra os cativos e contra ele. Conforme o correspondente, ao se desvencilhar dos ataques, feriu o capitão do mato, que teria fugido e ido ao encontro do comissário de polícia a quem se queixara sobre o ocorrido.

No fim das contas, o leitor afirmava que embora tendo sido atacado primeiro, e também seus escravos, o comissário de polícia não the dera razão. O correspondente informava ainda que, passados cinco dias, teriam ido dois cabos de polícia à sua casa para realizar busca e, depois de mais cinco dias, teria o comissário dado ordem expressa para que o correspondente se entregasse à polícia. Assim o correspondente teria feito $\mathrm{e}$, posteriormente, fora conduzido à presença de um senhor Junqueira, provavelmente ocupante de cargo superior ao do comissário, que the teria restituído a liberdade. ${ }^{50}$

Para além das acusações de abusos que pairavam sobre a polícia, havia ainda aquelas vinculadas a violações de conduta e à desvirtuação de seus agentes. Em 15 de janeiro de 1828, o correspondente que assinava como Atropelado pelas tais portarias escrevia à Astréa a fim de tornar pública sua indignação com determinadas ações e medidas da instituição policial.

A carta publicada no jornal trazia algumas considerações sobre a proibição da circulação de boiadas durante o dia pelas estradas e ruas da cidade, medida que teria sido estabelecida ainda nos tempos do primeiro intendente geral, Paulo Fernandes Viana. Entretanto, algum tempo depois, uma portaria promulgada por meio da Intendência Geral 
da Polícia estabeleceu que, em casos excepcionais, como o embarque de gado para bordo de navios, os proprietários pagariam dois cruzados e poderiam obter a autorização.

O fato que causava aversão ao correspondente era que, a despeito da legítima e excepcional causa, inúmeras boiadas teriam voltado a transitar nas ruas da cidade em qualquer momento do dia, bastando para isso que os proprietários pagassem os dois cruzados à polícia. ${ }^{51}$

O relato publicado na Astréa torna-se interessante inclusive no tocante à compreensão das próprias atividades policiais. Caberia à polícia, assim, regular e controlar a presença de animais nas ruas da cidade, conferindo ou negando as respectivas autorizações. Atividades que, no limite, ainda estariam ligadas a uma concepção de polícia como gestora do espaço urbano e da vida dos indivíduos.

O amigo das rondas, por sua vez, enviou ao periódico Aurora Fluminense uma correspondência na qual narrava um diálogo que havia escutado entre dois indivíduos enquanto subia a ladeira de Santa Tereza. Conforme o correspondente, os homens conversavam sobre os constantes roubos que se faziam na cidade e a respeito das rondas da polícia a fim de prevenir os delitos:

Pois então (queixava-se um) já não há rondas que vigiem à noite a segurança dos cidadãos? Há sim senhor (replicava o outro); porém são poucos os soldados e por isso não podem ser estas em tão grande número que não faltem para alguma parte. Essa é boa (Ihe torna o primeiro), pois são poucos os soldados para vigiarem as fazendas e vidas dos cidadãos, que pacíficos descansam na proteção que lhes promete a lei, e de sobejo para serem dispensados pelo sr. comandante Frias e estarem noites inteiras patrulhas à porta de particulares, enquanto estes engolfados nos prazeres celebram festas de família?52

A insatisfação com as ações empreendidas pela força policial também estaria presente na correspondência enviada pelo Seu assinante e publicada na Astréa em dezembro de 1828. No dia 16 de novembro daquele ano, soldados da Guarda Real teriam ouvido gritos no Arco do Teles em que se acusava a existência de ladrões no local. Os agentes policiais teriam encontrado Manoel José Soares, "que foi caixeiro do negociante José Jorge da Silva, e que este o deitou fora de sua casa por ladrão, o qual vinha correndo da parte do Arco para o largo do Paço, seguido das ditas vozes". ${ }^{53}$

Na carta enviada a Astréa, relatava-se que os soldados da Guarda do Paço teriam conseguido prendê-lo, embora o tal Manoel tivesse disparado com arma de fogo em

\footnotetext{
51 Astréa, n. 234, 15 jan. 1828, p. 968.

52 A Aurora Fluminense, n. 75, 4 ago. 1828, p. 312.

53 Astréa, n. 365, 4 dez. 1828, p. 1605.
} 
direção aos agentes e com ele, no momento da prisão, também se encontrassem um punhal e cartuchos de munição.

Embora o relato enviado ao periódico seja rico em detalhes, cabe mencionar o motivo principal de sua publicação. Ao que parece, ao conduzir o detido, os guardas do Paço teriam encontrado o comandante da Guarda da Polícia, o coronel Frias. Tal autoridade teria afirmado que o detido não era ladrão, nem criminoso. $E$, mesmo vendo as armas apreendidas na ação, teria dado "a entender que os soldados da Guarda do Paço foram os que introduziram o punhal e cartuchos embalados no preso, e que a pistola não era dele". 54

Afirmava o correspondente da Astréa:

Como, pois, vai o snr. coronel comandante da polícia advogar a causa desse malvado? Não é isso dar uma má ideia de si? E o mais, snr. redator, que o ladrão é tão conhecido dos snrs. da polícia que até o tenente Adrião desse mal aventurado corpo disse em certa parte que o ladrão era um pobre rapaz e que estava ali esperando falar a uma rapariga. Ora, isso é querer meter uma tranca pelos olhos da gente! Não é debalde que os snrs. ladrões andam tão atrevidos, porque contam com a impunidade e com a proteção do snr. coronel Frias e tem o snr. tenente Adrião para os desculpar. ${ }^{55}$

O crédulo dos impossíveis teria sua correspondência publicada no jornal no dia 13 de dezembro do mesmo ano. Segundo consta nesta edição, Manoel Jorge Vidal taberneiro - e Antônio da Silva Lappa - canteiro - teriam se envolvido em uma contenda, na qual Lappa tentara assassinar Vidal.

Os gritos por socorro foram logo ouvidos e o ajudante Guilherme José Varella teria ido ao encontro dos indivíduos, que foram presos em seguida. Lappa ainda teve sua bengala de estoque, com a qual ferira Vidal com cinco golpes e atentara contra 0 ajudante, apreendida. No dia seguinte, ambos os envolvidos teriam sido encaminhados ao estado maior da polícia, em que "o snr. coronel Frias conheceu do caso e não houve cadeia por meio de remessa feita ao juiz do bairro". ${ }^{56}$

O correspondente afirmava ao redator da Astréa que enquanto se esperava a fim de saber para que prisão seria enviado Silva Lappa, o acusado aparecera em casa, solto,

[...] dizendo claramente: o outro foi para a Misericórdia [Santa Casa] curar-se e eu fui logo solto e lá deixei tudo pago!! E não fui à presença de juiz algum, mas solto pelo comandante da polícia. E que me diz a esta, snr. redator? [...] Para presumirmos que ele o fizesse por desistência da parte do referido, também não podia ser; primeiro porque em tal caso o snr. coronel Frias não está autorizado para presidir a conciliação das partes; segundo porque em crimes de tal natureza nem o juiz o podia fazer, por ter neles grande parte de justiça. Consta que o

\footnotetext{
54 Astréa, n. 365, 4 dez. 1828, p. 1605.

55 Ibidem.

56 Astréa, n. 369, 13 dez. 1828, p. 1623-1624.
} 
criminoso diz que dera um conto de réis para ser solto! A quem o daria, snr. redator? Ao snr. Frias? Não pode ser, não, que não é desse caráter. Quem será a autoridade que venda a lei por um conto de réis, snr. redator? Eu não sei para onde atine, em caso de tal qualidade; o que sei é que o Lappa está em casa! E que segundo ele diz está tudo pago! E está? Deixei tudo pago! E o homem que está a espirar, snr. redator, quem há de pagar este assassínio? Está tudo pago e o Lappa em casa. Eu enlouqueço; acaso haveria alguma lei que derrogasse as que mandam prender e castigar os matadores? Eu não sei, o Lappa está em casa! Eu estou trêmulo, snr. redator; eu não sei se falo verdade ou minto, porque este caso não se pode acreditar, ainda vendo-se; mas o que sei é que está tudo pago e que o Lapa está em casa. ${ }^{57}$

Nos últimos dias de 1828, A Aurora Fluminense também trazia um questionamento no tocante às ações empreendidas pela força policial. Dessa vez, não seria por meio de um correspondente, como era comum na Astréa, mas por intermédio dos escritos de seu próprio redator. Narrava que nas noites anteriores àquela edição do periódico, datada de 29 de dezembro, uma ronda da polícia teria apalpado um menino, "achando-lhe unicamente na algibeira da calça um canivete de aparar pena".

Conforme o pequeno trecho publicado no jornal, os agentes policiais teriam se contentado em reter o canivete, liberando o garoto a fim de que fosse para sua casa. A questão principal trazida pelo relato dizia respeito ao seguinte trecho:

Pergunta-se: este indivíduo estava criminoso ou não? Se estava criminoso, qual era o castigo? Roubar-se-lhe o canivete? De nenhum modo; e então assim procedem as rondas? Deixamos ao snr. comandante da polícia a solução desta dúvida. ${ }^{58}$

A análise das fontes permite apreender algumas das considerações em voga no período sobre a polícia. De fato, não se pretende considerar os fatos descritos nos periódicos como verdades absolutas, mas é inegável que os discursos de insatisfação com as instituições policiais eram constantes e demandavam sua transformação. E é nesse sentido que importa considerá-los.

Em diferentes jornais, denúncias de arbitrariedades e corrupção se faziam presentes. Eram esses os pressupostos que legitimavam a defesa da extinção das instituições policiais criadas antes da independência e sua incompatibilidade com o sistema constitucional. As exorbitâncias cometidas pelos agentes policiais eram assim compreendidas a partir do desrespeito aos postulados sob os quais o novo Estado se estabelecia: a Constituição e as leis.

A ideia principal dizia respeito à existência de um antagonismo entre a Intendência Geral da Polícia e a Constituição. Por outro lado, alguns aspectos relacionados a uma

57 Astréa, n. 369, 13 dez. 1828, p. 1624.

58 A Aurora Fluminense, n. 134, 29 dez. 1828, p. 555. 
concepção mais ampla de polícia, atrelada à gestão da vida dos indivíduos em seus mais variados sentidos, permaneciam.

Tal perspectiva pode ser vislumbrada quando da instituição policial eram esperadas medidas efetivas de controle para o transporte de gado nas ruas da cidade; ou na correspondência enviada por Um do lugar, em 13 de setembro de 1828. Tratava-se de uma reclamação do correspondente, morador da região onde estava localizado o cemitério dos negros novos.

Os moradores da rua da Gamboa e Nova do Propósito já teriam requerido várias vezes a mudança do cemitério de localidade, mas não obtiveram sucesso. Contudo, o correspondente afirmava que teriam conseguido "uma providente portaria da Intendência Geral da Polícia (digo providente porque dos males o menor) proibindo que jamais se queimassem esteiras e ossos naquele cemitério" ${ }^{59}$

As maiores críticas, a priori, estariam vinculadas às ações dos agentes da Intendência e, sobretudo, de sua divisão militar, a Guarda Real. As oposições se dariam em virtude de as ações da polícia serem consideradas espionárias, ao fato de seus agentes não cumprirem as disposições constitucionais e as leis, bem como não respeitarem os direitos individuais estabelecidos. A reprovação estaria ainda relacionada ao caráter militar da instituição policial nas ações de patrulhamento das ruas; aliás, esse seria um tema importante nas discussões sobre as instituições policiais na década seguinte.

É nesse sentido que A Aurora Fluminense chamava atenção para a existência de um "espírito militar, que o antigo sistema teve o cuidado de espalhar por todo o Brasil", 60 afirmando que "só o tempo e a ilustração" ${ }^{61}$ poderiam apagar. Na mesma linha argumentativa, A Malagueta, periódico redigido pelo então deputado Luís Augusto May, asseverava a "confusão, a mescla civil e militar da repartição da polícia desde a sua criação no Brasil". 62

Com perfil um pouco distinto da Astréa e da Aurora Fluminense, A Malagueta se constituía como um jornal fundamentalmente de opinião. Se na Astréa as correspondências de leitores e assinantes comporiam quase que inteiramente as edições do periódico, na Aurora os artigos de opinião do redator se acomodavam junto às cartas

\footnotetext{
59 Astréa, n. 331, 13 set. 1828, p. 1368.

60 A Aurora Fluminense, n. 59, 25 jun. 1828, p. 243.

61 Ibidem.

62 A Malagueta, n. 74, 20 fev. 1829, p. 183.
} 
dos leitores. Na Malagueta, por sua vez, as edições consistiam, predominantemente, na apresentação dos pontos de vista de seu redator sobre os diversos temas.

Assim, ao comentar o caso publicado na Astréa pela correspondência de Pedro José Innosa, ${ }^{63}$ o redator da Malagueta afirmava sua preocupação com o estabelecimento das instituições no Brasil passados anos da promulgação da Constituição. Declarava que

[...] a Malagueta pouco ou nada tem a dizer neste caso do snr. coronel Frias, nem do tenente Adrião, nem mesmo do morador Innosa; o que a Malagueta tem a fazer é lamentar o estado em que se conserva a marcha de todas, ou quase todas, as coisas que dizem respeito às teses da Constituição, que afiançam a segurança individual e a independência, e irresponsabilidade do cidadão enquanto este está dentro da lei. A medo que no Rio de Janeiro se foge do grande critério do termo médio - ou bem os ladrões e malfeitores hão de andar soltos - ou bem se há de poder prender estrondosa e desgraçadamente um cidadão como Innosa, a quem o snr. Frias julgou dever mandar logo soltar por honra da corporação sem que para a prisão, nem para a soltura se apresentasse ordem alguma de magistrado ${ }^{64}$ (grifo nosso).

De fato, o que parecia afligir o sr. Augusto May, parlamentar e redator da Malagueta, dizia respeito à hibridização - ou mescla, conforme o próprio contemporâneo - do sistema constitucional, com o primado das leis, e das instituições antigas, em que os velhos métodos de uma polícia de pretensão absoluta, fruto da tradição da ilustração portuguesa $^{65}$, se faziam presentes.

A busca por um "termo médio", em que a ordem conseguisse suprimir os crimes, mas os arbítrios policiais fossem superados, era o grande desafio que se impunha para o processo de transformação das instituições policiais. A polícia, organizada sob a forma da Intendência e de sua força militar, a Guarda Real, não era conciliável com o sistema constitucional; era necessário encontrar outra possibilidade para o exercício do poder policial. Em meio a essa dificuldade, a instituição do juizado de paz começaria a despontar como possível solução para os problemas da administração policial e, ainda, judiciária. Nesse sentido, notabilizam-se nas páginas dos jornais desse período as expectativas colocadas no estabelecimento da magistratura eletiva.

63 O correspondente afirmava ao redator da Astréa que, estando em sua casa trabalhando como mestre sapateiro, no dia 9 de fevereiro de 1829, fora surpreendido por um homem que lhe perguntava se seu nome era Pedro José. Ao responder positivamente, o tal homem teria decretado a prisão do correspondente. A carta publicada na Astréa trazia detalhes sobre o ocorrido; contudo, de maneira geral, parece ter se tratado de mais um abuso cometido pela autoridade policial, uma vez que o correspondente afirmou ao tal homem, o tenente Adrião da Guarda da Polícia, que conhecia a Constituição e que tal prisão não poderia ser feita. Pedro José Innosa foi conduzido ao quartel da Guarda onde foi colocado na cadeia. Com a chegada do comandante da Guarda Real ao quartel, snr. Frias, a prisão foi revertida e o correspondente mandado para sua casa. Astréa, n. 391, 14 fev. 1829, p. 1715-1716.

64 A Malagueta. 1829, p. 184.

65 NEDER, Gizlene. Iluminismo jurídico-penal luso-brasileiro: obediência e submissão. 2. ed. Rio de Janeiro: Revan, 2007. 


\section{Os juízes de paz: muito mais que meros conciliadores}

Apenas com a promulgação da lei de 15 de outubro de 1827 os juízes de paz passariam a ter suas atividades regulamentadas, ainda que a previsão para sua instituição estivesse presente desde a outorga da Constituição de 1824.

Além do papel de conciliador entre as partes nos momentos preliminares do processo, seriam designadas aos juízes eletivos diversas funções, dentre as quais: julgar pequenas demandas; fazer separar os ajuntamentos em que houvesse "manifesto perigo de desordem"; colocar sob custódia os bêbados; evitar rixas; fazer com que não houvesse vadios nem mendigos, "obrigando-os a viver de honesto trabalho e corrigir os bêbados por vício, turbulentos e meretriz escandalosas", com obrigatoriedade da assinatura de termos de bem-viver; fazer destruir quilombos; fazer auto de corpo de delito; ter uma relação dos criminosos de seu distrito para fazer prendê-los; fazer observar as posturas policiais das Câmaras; vigiar sobre a conservação das matas; e dividir os distritos em quarteirões, nomeando para cada um deles um oficial que the informasse sobre todos os acontecimentos. ${ }^{66}$

No ano seguinte, com a lei que deu nova forma às Câmaras e estabeleceu o processo de eleição dos vereadores e juízes de paz, o processo iniciado cerca de um ano antes seria ampliado.

As posturas policiais das Câmaras Municipais ${ }^{67}$ tratariam de uma série de assuntos da alçada da Intendência Geral da Polícia e, sendo os magistrados eleitos os responsáveis por fazê-las serem observadas, acabariam assumindo um lugar importante no ordenamento jurídico que tratava do poder policial. A magistratura eletiva se estabelecia nos anos finais da década de 1820 congregando muito mais funções que aquelas previstas inicialmente, de modo que os liberais do período teriam feito dos juízes de paz uma espécie de porta-voz para seus próprios postulados políticos. ${ }^{68}$

\footnotetext{
${ }^{66}$ BRASIL, 1827.

${ }^{67}$ As posturas diziam respeito, de maneira geral, a aspectos da vida cotidiana dos indivíduos, e não necessariamente a ações de segurança como, por exemplo, iluminação, abastecimento de água, estabelecimento de cemitérios, matadouros públicos ou particulares, etc. Estariam, assim, vinculadas a uma concepção de polícia relacionada à administração da cidade. BRASIL, 1828., Título III.

${ }^{68}$ FLORY, Thomas. El juez de paz y el jurado em el Brasil imperial. Ciudad de México: Fondo de Cultura Económica, 1986.
} 
O fim da Intendência Geral da Polícia era defendido na relação com o estabelecimento dos juizados de paz. Esse era o posicionamento apresentado na Aurora Fluminense ao comentar o projeto de lei que tramitava na Assembleia a respeito da extinção da Intendência da Polícia:

[...] ainda que não fosse consequência necessária da sua incompatibilidade com o sistema constitucional bastaria, para dever acabar, a razão de tornar-se quase inútil, ficando o que tem de bom às Câmaras e aos juízes de paz. ${ }^{69}$

A extinção dos comissários de polícia também seria um tema abordado em relação ao estabelecimento da magistratura eletiva. O providente, correspondente da Astréa que teve sua carta publicada em 17 de janeiro de 1829, escrevia sobre os questionamentos acerca do novo cargo e seu desacordo com os comissários estabelecidos por portaria, bem como com os juízes almotacés.

$\mathrm{Na}$ perspectiva do correspondente, tendo estabelecido a lei de 1828 que as atividades policiais eram prerrogativa dos juízes de paz e a revogação de todas as disposições contrárias, estava desfeito o problema, "ficando nulas as duas autoridades, comissário de polícia e almotacé"70.

A extinção do cargo de comissário de polícia foi comemorada por outro periódico da Corte na edição publicada em 21 de janeiro de 1829. Segundo constava nesta edição, o intendente da polícia havia determinado a abolição desse cargo tão logo os juízes de paz iniciassem o exercício de suas funções; assim "o snr. intendente da polícia havia reconhecido a incompatibilidade da continuação destes magistrados criados por portaria e oficiou ao sr. Ministro das Justiças, que prontamente providenciou". ${ }^{71}$

Era nessa mesma linha que o correspondente Um cidadão escrevia para o redator da Aurora afirmando que "o corpo da polícia não goza daquela confiança que Ihe convinha"; 72 a forma adequada de reorganizar a instituição, em seu entendimento, seria "entregar sua direção e mando aos magistrados da escolha do povo e a quem foi confiado o cuidado da paz pública". ${ }^{73}$

As considerações tecidas na carta publicada no jornal de Evaristo da Veiga iam além, estabelecendo que "se os juízes de paz são obrigados a dissipar os ajuntamentos

\footnotetext{
69 A Aurora Fluminense, n. 44, 16 maio 1828, p. 180.

70 Astréa, n. 380, 17 jan. 1829, p. 1673.

71 A Aurora Fluminense, n. 144, 21 jan. 1829, p. 595.

72 A Aurora Fluminense, n. 156, 20 fev. 1829, p. 644.

73 lbidem.
} 
tumultuosos, a coibir os motins, como o poderão conseguir sem que esteja nas suas mãos uma força que Ihes sirva de meio repressivo?". ${ }^{74}$

É possível estabelecer que, de maneira geral, a ideia predominante nos periódicos durante os anos finais da década de 1820 se vinculava ao juizado de paz enquanto parte das soluções constitucionais para os problemas da polícia. A magistratura eletiva, em que os cidadãos teriam a possibilidade de escolher os seus juízes, seria uma medida eficaz para o controle dos arbítrios cometidos pela instituição policial de então.

Assim, tornava-se de suma importância a definição daqueles que seriam elegíveis, ou melhor, das características esperadas dos aptos a ocupar um cargo tão importante na nova organização policial e judiciária. Considerando o papel pedagógico que se atribuíam os redatores do período, ${ }^{75}$ a ideia de instruir a população para a eleição dos magistrados esteve presente em algumas edições dos jornais.

Antes mesmo da promulgação da lei de 1828, a eleição dos juízes de paz já figurava nas páginas dos periódicos. Como a lei de 15 de outubro de 1827 estabeleceu que os juízes de paz seriam eleitos pela mesma forma como se elegiam os vereadores das Câmaras, em algumas cidades o processo eleitoral teria se iniciado ainda no começo de 1828.

Em 12 de abril daquele ano, o periódico Aurora Fluminense supunha que a lei dos juízes se vinculava ao projeto das municipalidades, ainda em discussão na Assembleia, pois "não podia ser a intenção dos legisladores que os juízes de paz fossem eleitos pelo método imperfeito dos pelouros, em que só costuma valer uma cabala circunscrita em cada lugar a um estreito círculo de pessoas influentes". ${ }^{76}$ Nesse sentido, marcava a necessidade de o governo informar às localidades sobre a forma para a eleição dos magistrados.

\footnotetext{
74 A Aurora Fluminense, n. 156, 20 fev. 1829, p. 644.

${ }^{75} \mathrm{~A}$ imprensa periódica que despontava nesse período atribuía a si um papel de suma importância, sendo responsável pela instrução e civilização dos seus leitores. Trecho interessante sobre este aspecto pode ser encontrado em A Aurora Fluminense, n. 283, 28 dez. 1829:

"O anúncio de que vai aparecer uma nova publicação periódica é sempre para nós uma notícia agradável, persuadidos como estamos de que estes veículos de luzes políticas são necessários a um povo que começa a sua existência livre, mais do que a qualquer outro. Faltando-Ihe aqueles elementos que o espírito de associação e o desenvolvimento prático de outras instituições subministram às nações mais adiantadas na cultura social, os periódicos são aí quase o único meio de se instruir a população no conhecimento dos seus direitos e grandes interesses, bem como de se manter o calor vital do espírito público, sem o qual não há liberdade nem verdadeira vida política".

Sobre o assunto: MOREL; BARROS, 2003.
}

76 A Aurora Fluminense, n. 33, 12 abr. 1828, p. 135. 
A eleição dos juízes ocorreria na Corte apenas em janeiro de 1829. Entretanto, desde 1828 as instruções dadas aos leitores sobre como escolher os magistrados locais poderiam ser encontradas nas páginas dos periódicos.

Em 19 de maio de 1828, era publicado o seguinte trecho:

\begin{abstract}
É preciso que os liberais, que os verdadeiros amigos da pátria, aqueles que desejam a ordem, que só se pode fundar na observância exata da Constituição, estejam de atalaia e desde já trabalhem em averiguar miudamente as escolhas que devem fazer. A sua consciência o manda e a sua felicidade está pendente dos esforços que empregaram para esse fim; porque dos votos que dermos, das pessoas que nomearmos nascerá a ventura ou a desgraça do Brasil; haverá ou tranquilidade e cumprimento das leis, ou anarquia e arbítrio na execução delas. Este ano as eleições são de grande peso: não só teremos de escolher os deputados para a próxima legislatura; porém muitas instituições constitucionais, que necessitam de eleição popular vão começar a ter andamento e dos primeiros nomeados para ocuparem certos cargos, nascerá o bom conceito ou descrédito da instituição. Os juízes de fato hão agora de ser substituídos e há a escolher os juízes de paz e talvez os membros das Câmaras Municipais. Vigilância e zelo; indiferença e o egoísmo nos perderão no sistema antigo e são incompatíveis como o novo: tratemos quanto antes de indagar escrupulosamente quais são os cidadãos dignos de funções tão importantes, para ao depois votarmos segundo a nossa íntima convicção. ${ }^{77}$
\end{abstract}

As orientações para a escolha dos candidatos das municipalidades - vereadores e juízes de paz - também estariam presentes na edição de 12 de dezembro de 1828 da Aurora. Para a eleição dos vereadores e juízes de paz, o jornal aconselhava os votantes ${ }^{78}$ a optarem por candidatos probos e seguidores do sistema constitucional; além disso, orientava a escolha por aqueles a quem chamava de homens próprios, "homens que já tiverem um estabelecimento de que possam subsistir com decência". ${ }^{79}$

Essa ideia seria novamente apresentada na edição de 16 de janeiro de 1829, já após a eleição dos magistrados. No texto publicado nesta edição da Aurora, o redator se contrapunha ao pagamento de remuneração aos juízes de paz, afirmando que

[...] se se decretar ordenado aos juízes de paz, acontecerá que estes se reputarão funcionários do governo, por cuja mão recebem o seu pagamento; que o estipêndio que hoje se julga suficiente daqui a algum tempo o não será, crescendo com o gozo a cobiça; que os intrigantes procurarão esses lugares, como um modo de vida, e perder-se-á inteiramente a liberdade da instituição. Pelo outro lado, alguns inconvenientes de oferecem; mas esses mesmos inconvenientes trarão

\footnotetext{
77 A Aurora Fluminense, n. 45, 19 maio 1828, p. 185.

78 Considerando a constituição de 1824 , os eleitores seriam aqueles escolhidos mediante voto indireto dos cidadãos ativos nas assembleias paroquiais - as eleições primárias. Apenas os eleitores poderiam votar para escolher os "representantes da nação". Já os cidadãos votantes poderiam votar nas eleições primárias, para a escolha dos eleitores, e para a escolha das autoridades municipais, como os juízes de paz. Para as eleições primárias, os votantes tinham que cumprir alguns requisitos, os mais importantes relacionados à idade e à renda: maiores de 25 anos, via de regra, e possuírem renda líquida anual maior quem cem mil reis. Já na categoria de eleitores, não poderiam ser admitidos aqueles que não tinham voto nas eleições primárias e, sobretudo, aqueles que possuíam uma renda líquida anual menor que duzentos mil réis.

79 A Aurora Fluminense, n. 128, 12 dez. 1828, p. 531.
} 
consigo o remédio, elegendo-se nas paróquias aquelas pessoas cuja abastança e posição social lhes faça menos penoso semelhante sacrifício. ${ }^{80}$

A perspectiva anunciada nas edições da Aurora é elucidativa em dois sentidos. Em primeiro lugar, demonstrava a necessidade de o exercício do poder judiciário ser concebido de forma independente - no limite, a tese central da separação dos poderes. A forma adequada para o alcance deste objetivo, sob esse ângulo, seria a eleição dos magistrados; seriam os juízes eleitos os representantes da população no judiciário; o que, em princípio, atestaria seu posicionamento autônomo em relação ao governo. Por outro lado, apresentava uma determinada concepção para a escolha desses membros, pautada em postulados não tão distantes daqueles de outrora. As eleições seriam, de fato, a escolha dos homens bons. ${ }^{81}$

Havia, ainda, um aspecto interessante nos jornais em fins da década de 1820 acerca da instituição dos juízes eletivos. A ausência de uma estatística que pudesse subsidiar a gestão do novo Estado era reclamada no fim de 1828:

[...] sem alguma base estatística tanto da quantidade dos habitantes como da soma dos produtos, mortalidade, etc., não se poderá avançar um passo na administração do Brasil e se caminhará às cegas e apalpando. ${ }^{82}$

Como elemento fundamental à construção do Estado, aparecia a noção de estatística. A formulação de um saber - na verdade de saberes - a respeito dos diferentes campos de atuação do exercício do poder do Estado, profundamente relacionado à arte de governar, ${ }^{83}$ se apresentava.

Nesse sentido, a solução dada, a priori, nas páginas dos jornais nos anos finais da década de 1820 era destinar às autoridades locais essa tarefa:84

As noções estatísticas que hoje nos faltam, e sem as quais não podemos dar um passo; o conhecimento das necessidades locais transmitindo por todas as veias da administração, desde as municipalidades até o Congresso Nacional, serão poderosos elementos para mais fácil coordenação de leis promotoras da indústria, proporcionando-se a todas as classes do povo o bem-estar e a fruição dos cômodos da vida, rodas sobre que anda toda a liberdade culta. ${ }^{85}$

Já no início de 1829, logo após a eleição dos juízes de paz da Corte, o periódico comandado por Evaristo da Veiga chamava atenção para o que considerava ser uma necessidade urgente para os novos magistrados:

\footnotetext{
80 A Aurora Fluminense, n. 142, 16 jan. 1829, p. 586. hierarquias sociais: MATTOS, 2005.

82 A Aurora Fluminense, n. 120, 21 nov. 1828, p. 500.

83 FOUCAULT, 2012.

84 A Aurora Fluminense, n. 120.

85 A Aurora Fluminense, n. 129, 15 dez. 1828, p. 533.
}

81 Sobre o processo da independência e do estabelecimento da liberdade política não ter se desdobrado em um projeto de unidade ou de igualdade, mas mantido, de certa forma, um sentimento aristocrático e as 
Um dos primeiros trabalhos a que tem de proceder os snrs. juízes de paz, logo que tomem posse dos seus lugares, é formar o censo de suas respectivas paróquias para se fazer a subdivisão dos distritos, nomeação dos oficiais, etc. Este trabalho não é de pequena monta, nem oferece poucas dificuldades num país aonde nunca se cuidou em ordenar a estatística, nem ao menos da capital; aonde quase todos fogem de dar com exatidão as informações que se lhe pedem com temor de recrutamento, milícias e outras alcavalas. ${ }^{86}$

As dificuldades encontradas pelos juízes de paz não seriam apenas no tocante à construção das estatísticas, conforme previa-se nas folhas dos periódicos. Antes do fim da década de 1820, já figuravam nos jornais relatos de dificuldades encontradas pelos juízes eletivos. De fato, havia alguns apontamentos a respeito de aspectos considerados importantes, mas que não tinham sido ainda implementados. Fora nesse sentido que, em 30 de janeiro de 1829, A Aurora afirmava que na lei dos magistrados eletivos havia menções à casa de correção, casa de trabalho, mas que tais casas ainda não existiam e que o novo sistema penal deveria "girar sobre a grande roda do sistema de prisões". ${ }^{87}$

As críticas, ainda que brandas, também iam no sentido de que a lei que regulamentou as atividades dos juízes de paz não tinha marcado as atribuições dos oficiais de quarteirão. Pairava a dúvida se "seriam meros vigias do juiz de paz e zeladores da ordem de seu pequeno distrito", caso em que qualquer indivíduo poderia desempenhar a função; ou se seriam responsáveis por "fazer as intimações e outros atos próprios dos atuais oficiais de justiça". ${ }^{88}$

$\mathrm{Na}$ Malagueta de 24 de fevereiro de 1829, o seu redator apresentava suas preocupações relacionadas à magistratura recém-instalada. Incomodava-se com 0 excesso de atribuições conferidas aos juízes de paz e ressentia-se pela possibilidade de esses magistrados serem submetidos ao intendente da polícia, "cuja autoridade não é a própria para conhecer nem administrar os juízes de paz". ${ }^{89}$

$\mathrm{Na}$ concepção de Augusto May, os superiores dos juízes eletivos eram as municipalidades, ou seja, a Câmara Municipal. Além disso, asseverava que a nação vivia "na expectativa de abolição da Intendência Geral da Polícia e da divisão das suas atribuições entre instituições" 90 a fim de fazer jus ao estabelecido na Constituição do Império. ${ }^{91}$

${ }^{86}$ A Aurora Fluminense, n. 146, 28 jan. 1829, p. 602.

${ }^{87}$ A Aurora Fluminense, n. 148, 30 jan. 1829, p. 610.

${ }^{88}$ A Aurora Fluminense, n. 170, 27 mar. 1829, p. 700.

${ }^{89}$ A Malagueta, n. 75, 24 fev. 1829, p. 188.

$90 \mathrm{lbidem}$.

91 As preocupações do redator da Malagueta acabariam, grosso modo, se consolidando na década seguinte. A Intendência Geral da Polícia deixaria de existir, bem como sua Guarda Real. Mas o Código de Processo Criminal de 1832, que não definiu de maneira clara as atribuições policiais dos magistrados 
Em linha semelhante, A Aurora Fluminense publicara, alguns dias antes, um artigo no qual discorria sobre a existência de representações e queixas contra os juízes de paz em diferentes províncias. Na edição de 16 de fevereiro de 1829, afirmava a presença de insatisfações partindo de diferentes figuras: autoridades judiciárias, presidentes de províncias e, ainda, de particulares. A explicação apresentada pelo jornal era no sentido de que tais reclamações seriam

[...] um resultado natural da posição em que estão colocados os juízes de paz. A lei lhes assinou muita cópia de atribuições e não lhes deu os meios para desempenhá-las, não marcou os limites das jurisdições, fazendo assim nascer conflitos a cada hora. ${ }^{92}$

Havia, ainda, uma outra razão. A "pouca complacência" com que a instituição teria sido enxergada desde a sua criação pelos magistrados togados. Sob o prisma apresentado no jornal, "homens do poder não simpatizaram facilmente com estes magistrados eletivos e tirados do meio do povo". ${ }^{93}$

O apontamento não era infundado. De fato, o lugar a que seriam alçados os juízes de paz, sobretudo na década de 1830, após a promulgação do Código de Processo Criminal, não seria aceito sem ressalvas por membros de uma burocracia judicial, formados na tradição dos cursos jurídicos luso-brasileiros, primeiro em Coimbra, depois em Olinda e São Paulo. ${ }^{94}$

O processo iniciado na segunda metade da década de 1820 teria como principal característica o estabelecimento da magistratura eletiva, a partir da lei de 1827, conferindo-Ihe uma série de atribuições para além daquela estabelecida quando de sua previsão constitucional. Da mesma forma, a promulgação da lei que reformulou as Câmaras Municipais, tirando-Ihes suas atribuições políticas e garantindo-Ihes funções administrativas, reforçou o juizado de paz na nova organização policial e judiciária que começava a se estabelecer.

A promulgação do Código de Processo Criminal do Império, por meio da lei de 29 de novembro de 1832, seria a consolidação de um processo iniciado ainda em 1827,

eletivos, estabeleceu de maneira precária o cargo de chefe de polícia - um entre os juízes de Direito nas cidades mais populosas. No ano seguinte, o decreto de 29 de março de 1833 determinaria que ao chefe de polícia caberia a fiscalização das atividades empreendidas pelos juízes de paz. Na Corte, as atividades dos juízes de paz ficariam durante toda a década de 1830 sob o comando do chefe de Polícia Euzébio de Queirós.

${ }_{92}$ A Aurora Fluminense, n. 154, 16 fev. 1829, p. 634.

93 Ibidem.

${ }^{94}$ FLORY, 1986, p. 34.

Sobre as semelhanças e complementaridades entre os cursos jurídicos no Brasil e em Portugal: NEDER, 2007; SILVA, Mozart Linhares. A reforma pombalina e o Direito moderno luso-brasileiro. Justiça \& História, Porto Alegre, v. 2, n. 4, p. 1-24, 2002. 
início da década liberal. ${ }^{95}$ Entretanto, faz-se importante apreender o quanto de ruptura, permanência e hibridizações houve nesse processo em que o novo sistema constitucional se misturava e mesclava-se às instituições do Antigo Regime. O objetivo deste artigo, nesse sentido, foi tentar fornecer um breve panorama a respeito desse processo, no âmbito das instituições policiais, a partir de discursos políticos presentes em alguns periódicos do período.

\section{Considerações finais}

Após a independência e, sobretudo, a promulgação da Constituição, uma série de transformações institucionais seria iniciada na tentativa de que o novo Estado se adequasse ao primado das leis e da constitucionalidade. Nesse processo, alavancado pelos trabalhos da primeira legislatura, iniciada em 1826, o Direito e as instituições relacionadas à administração da justiça seriam considerados temas prioritários.

A promulgação da lei de 15 de outubro de 1827, que regulamentou as atividades dos juízes de paz, e da lei de $1^{\circ}$ de outubro de 1828 , que deu nova forma às Câmaras Municipais, marcando o processo de eleição para as autoridades locais, desempenharam papel fundamental.

Ainda assim, nesse ínterim, o Estado convivia com instituições criadas sob o sistema antigo, caso da Intendência Geral da Polícia e da sua divisão militar, a Guarda Real. A necessidade de transformação dessas instituições, tidas como incompatíveis com o sistema constitucional, era premente. Os motivos e justificativas que atestavam a incompatibilidade da polícia, tal como se achava estabelecida, com a Constituição figuravam nas páginas dos jornais do período e diziam respeito, majoritariamente, a acusações de abusos de poder, arbitrariedades e desrespeito às disposições constitucionais e legais.

Por sua vez, parte das soluções para a reestruturação da polícia era concebida a partir do estabelecimento da magistratura eletiva; seriam os juízes de paz - de escolha pelo voto e não pelo governo - as autoridades adequadas para desempenharem as atividades policiais, longe do arbítrio, dos abusos, do despotismo.

Importante ressaltar, contudo, que as modificações nas instituições ainda não romperiam com uma concepção abrangente de polícia, tal qual estabelecida no Antigo 
Regime, relacionada à administração do espaço, à sua regulação, ao ordenamento da vida social.

Os posicionamentos presentes nos jornais ajudam a compreender as ideias acerca da polícia no período, o que a instituição poderia e deveria ser, aquilo de que deveria se apartar. Nas páginas dos periódicos nos anos finais da década de 1820, a polícia tal qual se achava organizada deveria ser abolida a fim de que a magistratura eletiva - e constitucional - pudesse realizar suas atividades.

Importante mencionar, contudo, que a própria imprensa periódica neste momento se consolidava enquanto novo espaço de sociabilidade nos processos de disputa e enfretamento políticos. A dinâmica política daquele momento se vinculava, sem dúvida, ao papel fundamental desempenhado pela imprensa. Cabe, inclusive, observar que a projeção alcançada pelos periódicos rendeu a Luís Augusto May e Evaristo da Veiga eleições para a Assembleia Geral.

$\mathrm{Na}$ década seguinte, com a promulgação do Código de Processo Criminal, os juízes de paz ganhariam ainda mais prestígio e importância no ordenamento policial e judiciário que se estabeleceria nos anos iniciais da Regência. A despeito disso, seria possível observar algumas permanências das concepções policiais existentes nos anos anteriores.

A Intendência Geral teria suas atividades encerradas, a Guarda Real também. Mas ao lado da Secretaria de Polícia, constituída por seus inspetores de quarteirão, juízes de paz e chefe de polícia, estariam os Guardas Municipais Permanentes, membros de um corpo militarizado responsável pela ordem nas ruas.

O processo de constituição das instituições policiais ao longo do século XIX foi marcado por transformações. A análise dos discursos políticos em circulação sobre a polícia pode ser uma etapa importante para compreendê-lo a partir de uma concepção mais ampla, que se proponha a entendê-lo como aspecto fundamental das relações de poder que se estabeleciam no oitocentos, evidenciando as disputas e embates políticos a seu respeito.

\section{Referências}

BRASIL. Congresso Nacional. Câmara dos Deputados. Alvará de 10 de maio de 1808. 1808. Crêa o logar de Intendente Geral da Policia da Corte e do Estado do Brazil. Disponível em: <http://www2.camara.leg.br/legin/fed/alvara/anterioresa1824/alvara-4014910-maio-1808-572058-publicacaooriginal-95179-pe.html>. Acesso em: 20 nov. 2015. 
BRASIL. Congresso Nacional. Câmara dos Deputados. Decreto de 13 de maio de 1809. 1809. Crêa a divisão militar da Guarda Real da Policia no Rio de Janeiro. Disponível em: <http://www2.camara.leg.br/legin/fed/decret_sn/anterioresa1824/decreto-40054-13-maio1809-571685-publicacaooriginal-94831-pe.html>. Acesso em: 20 nov. 2015.

BRASIL. Presidência da República. Casa Civil. Subchefia para Assuntos Jurídicos. Constituição política do Império do Brasil (de 25 de março de 1824). 1824. Disponível em: <http://www.planalto.gov.br/ccivil_03/Constituicao/Constituicao24.htm>. Acesso em: 6 abr. 2016.

BRASIL. Congresso Nacional. Câmara dos Deputados. Lei de 15 de outubro de 1827. 1827. Crêa em cada uma das freguezias e das capellas curadas um Juiz de Paz e supplente. Disponível em: <http://www2.camara.leg.br/legin/fed/lei_sn/1824-1899/lei38396-15-outubro-1827-566688-publicacaooriginal-90219-pl.html>. Acesso em: 18 dez. 2015.

BRASIL. Presidência da República. Casa Civil. Subchefia para Assuntos Jurídicos. Lei de $1^{\circ}$ de outubro de 1828. 1828. Dá nova fórma ás Camaras Municipaes, marca suas attribuições, e o processo para a sua eleição, e dos Juizes de Paz. Disponível em: <http://www.planalto.gov.br/ccivil_03/leis/LIM/LIM-1-10-1828.htm>. Acesso em: 6 abr. 2016.

CAMPOS, Adriana P. O farol da boa prática judiciária: dois manuais para instrução dos juízes de paz. In: SIMPÓSIO NACIONAL DE HISTÓRIA. LUGARES DOS HISTORIADORES: VELHOS E NOVOS DESAFIOS, 28, 2015, Florianópolis. Anais eletrônicos.... Florianópolis: ANPUH, 2015. Disponível em: <http://www.snh2015.anpuh.org/resources/anais/39/1428359222_ARQUIVO_FloripaAnpuh.pdf>. Acesso em: 8 abr. 2016.

CARVALHO, José Murilo. História intelectual no Brasil: a retórica como chave de leitura. Topoi, Rio de Janeiro, n. 1, p. 123-152, jan./dez. 2000.

COTTA, Francis Albert. Matrizes do sistema policial brasileiro. Belo Horizonte: Crisálida, 2012.

FLORY, Thomas. El juez de paz y el jurado em el Brasil imperial. Ciudad de México: Fondo de Cultura Económica, 1986.

FOUCAULT, Michel. "Omnes et singulatim": uma crítica da razão política. In: MOTTA, Manoel Barros da (Org.). Ética, estratégia, poder-saber. 3. ed. Rio de Janeiro: Forense Universitária, 2012, v. 4, p. 348-378. Coleção Ditos \& Escritos.

GUERRA, François-Xavier. De la política antigua a la política moderna: algunas proposiciones. Anuario IEHS, Buenos Aires, n. 18, p. 201-212, 2003.

HOLLOWAY, Thomas H. Polícia no Rio de Janeiro: repressão e resistência numa cidade do século XIX. Rio de Janeiro: Fundação Getúlio Vargas, 1997.

LOPES, José Reinaldo de Lima. Iluminismo e jusnaturalismo no ideário dos juristas da primeira metade do século XIX. In: JANCSÓ, Istvan (Org.). Brasil: formação do Estado e da nação. São Paulo: Hucitec, 2003. p. 195-218. 
MATTOS, Ilmar Rohllof. Construtores e herdeiros: a trama dos interesses na construção da unidade política. Almanack Brasiliense, São Paulo, n. 1, p. 8-26, 2005.

MOREL, Marco; BARROS, Mariana M. Palavra, imagem e poder: o surgimento da imprensa no Brasil do século XIX. Rio de Janeiro: DP\&A, 2003.

MOREL, Marco. As transformações dos espaços públicos: imprensa, atores políticos e sociabilidades na cidade imperial (1820-1840). São Paulo: Hucitec, 2005.

NEDER, Gizlene. Iluminismo jurídico-penal luso-brasileiro: obediência e submissão. 2. ed. Rio de Janeiro: Revan, 2007.

NEVES, Lúcia M. B. P. Corcundas e constitucionais: a cultura política da independência (1820-1822). Rio de Janeiro: Revan, 2003.

SEELAENDER, Airton C. L. A "polícia" e as funções do Estado: notas sobre a "polícia" do Antigo Regime. Revista da Faculdade de Direito, Curitiba, n. 49, p. 73-87, 2009.

SILVA, Maria Beatriz Nizza da. A Intendência-Geral da Polícia: 1808-1821. Acervo: Revista do Arquivo Nacional, Rio de Janeiro, v. 1, n. 2, p. 137-251, jul./dez. 1986.

SILVA, Mozart Linhares. A reforma pombalina e o Direito moderno luso-brasileiro. Justiça \& História, Porto Alegre, v. 2, n. 4, p. 1-24, 2002.

SLEMIAN, Andréa. Os canais de representação política nos primórdios do Império: apontamentos para um estudo da relação entre Estado e sociedade no Brasil (18221834). Lócus: Revista de História, Juiz de Fora, v. 13, n. 1, p. 34-51, 2007.

SODRÉ, Nelson Werneck. História da imprensa no Brasil. 4. ed. Rio de Janeiro: Mauad, 1999.

VELLASCO, Ivan. O juiz de paz e o Código do Processo: vicissitudes da justiça imperial em uma comarca de Minas Gerais no século XIX. Justiça \& História, Porto Alegre, v. 3, n. 6, p. 65-93, 2003. Disponível em: <https://bdjur.stj.jus.br/jspui/bitstream/2011/66121/juiz_paz_codigo_vellasco.pdf>. Acesso em: 18 abr. 2016. 